\title{
Senescence of human fibroblasts induced by oncogenic Raf
}

\author{
Jiyue Zhu, ${ }^{1,3}$ Douglas Woods, 2,3 Martin McMahon, ${ }^{2,4}$ and J. Michad Bishop ${ }^{1}$ \\ ${ }^{1}$ Department of Microbiology and Immunology and G.W. Hooper Foundation, U niversity of California at San Francisco \\ (UCSF), California 94143-0552 USA; ${ }^{2}$ Department of Cell Signaling, DN AX Research Institute, \\ Pal o AIto, California 94304-1104 USA
}

The oncogenes RAS and RAF came to view as agents of neoplastic transformation. However, in nomal cells, these genes can have effects that run counter to oncogenic transformation, such as arrest of the cell division cycle, induction of cell differentiation, and apoptosis. Recent work has demonstrated that RAS elicits proliferative arrest and senescence in normal mouse and human fibroblasts. Because the Raf/MEK/MAP kinase signaling cascade is a key effector of signaling from Ras proteins, we examined the ability of conditionally active forms of Raf-1 to elicit cell cycle arrest and senescence in human cells. Activation of Raf-1 in nonimmortalized human lung fibroblasts (IMR-90) led to the prompt and irreversible arrest of cellular proliferation and the premature onset of senescence. Concomitant with the onset of cell cycle arrest, we observed the induction of the cyclin-dependent kinase (CDK) inhibitors p21 ${ }^{\mathrm{Cip1}}$ and p16 ${ }^{\text {nk4a }}$. Ablation of p53 and P21 ${ }^{\mathrm{Cip1}}$ expression by use of the E6 oncoprotein of HPV16 demonstrated that expression of these proteins was not required for Raf-induced cell cycle arrest or senescence. Furthermore, cell cycle arrest and senescence were elicited in IMR-90 cells by the ectopic expression of p16 ${ }^{1 \mathrm{nk} 4 a}$ alone. Pharmacological inhibition of the Raf/MEK/MAP kinase cascade prevented Raf from inducing p16 ${ }^{1 \text { nk4a }}$ and also prevented Raf-induced senescence We conclude that the kinase cascade initiated by Raf can regulate the expression of p16 $^{1 \text { nk4a }}$ and the proliferative arrest and senescence that follows. Induction of senescence may provide a defense against neoplastic transformation when the MAP kinase signaling cascade is inappropriately active.

[Key Words: Raf; MAP kinase signaling; senescence; oncogenesis]

Received June 8, 1998; revised version accepted August 5, 1998.

$\mathrm{N}$ ormal cells proliferate in vitro for a finite number of cell divisions after which they enter a state known as senescence (Hayflick and M oorhead 1961; Campisi 1996, 1997). Senescent cells withdraw irreversibly from the cell division cycle, but remain viable indefinitely, develop a distinctive morphology, and display characteristic phenotypic markers, such as the senescence-associated, acidic $\beta$-galactosidase activity (SA- $\beta$-gal; Dimri et al. 1995). Although the biochemical mediators of senescence in human cells remain uncertain, candidates include the p53 tumor suppressor protein, the cyclin-dependent kinase (CDK) inhibitors $\mathrm{p} 21^{\mathrm{Cip1}}$ and $\mathrm{p} 16^{\mathrm{Ink} 4 \mathrm{a}}$, and regulators of telomere length and function, such as telomerase and TRF1 and TRF2. Increased expression of $\mathrm{p} 53, \mathrm{p} 16^{\mathrm{Ink} 4 a}$, and $\mathrm{p} 21^{\mathrm{Cip1}}$ is detected in a variety of senescent cells, and overexpression of telomerase leads to immortalization of human cells in culture (Kulju and Lehman 1995; Alcorta et al. 1996; Hara et al. 1996; Reznikoff et al. 1996; Shay and Bacchetti 1997; Bodnar et al. 1998; van Steensel et al. 1998). Furthermore primary

\footnotetext{
${ }^{3}$ These authors contributed equally to this work.

${ }^{4}$ Corresponding author. Present address: Cancer Research Institute, UCSF Cancer Center, San Francisco, California 94145 USA.

E-MAIL mcmahon@cc.ucsf.edu; FAX (415) 502-3179.
}

human cells that are deficient in the expression of p21 ${ }^{\text {Cip1 }}$ have increased replicative capacity in vitro (Brown et al. 1997). p53, p16 ${ }^{\text {Ink4a }}$, and p21 ${ }^{\text {Cip1 }}$ can arrest the cell division cycle: $\mathrm{p} 21^{\mathrm{Cip1}}$ and $\mathrm{p} 16^{\mathrm{Ink} 4 \mathrm{a}}$ do so by inhibiting CDKs required for progression through the cell cycle (Lees 1995), and p53 does so by inducing the expression of p21 ${ }^{\mathrm{Cipl}}$ (El-Deiry et al. 1993).

Cell lines derived from most tumors are capable of extended proliferation as if the capability to become senescent has been somehow repressed or lost. Accordingly, either $\mathrm{p53}, \mathrm{p} 16^{\mathrm{Ink} 4 a}$, or both are frequently defective in tumor cells (Hall and Peters 1996; Hainaut et al. 1997), and restoration of p53 to deficient tumor cells elicits prompt senescence (Sugrue et al. 1997). Furthermore, tumor cells frequently express telomerase activity, which may contribute to the extended proliferation of these cells in culture (Meyerson et al. 1997). Clearly the extension of proliferative life span might make an important contribution to tumorigenesis by increasing the likelihood that mutant variants of cells can arise.

Oncoproteins such as Ras and Raf can transform established lines of cells to neoplastic growth (Stanton et al. 1989; Samuels et al. 1993). However, in cultures of normal cells, these two genes can have paradoxical effects, including arrest of the cell cycle, differentiation, or 
even apoptosis (O'Shea et al. 1996; Kauffmann-Zeh et al . 1997; Lloyd et al. 1997; Woods et al. 1997). In culture, Ras and Raf transform normal cells only with the cooperation of other gene products, such as E1A, T-antigen, or $\mathrm{Myc}$, which apparently serve to extend the proliferative life span of the cells (Hunter 1991). Recent work has shown that the $\mathrm{H}$-Ras oncoprotein can also el icit premature senescence in IM R-90 cells, a widely studied strain of human fibrobl asts derived from lung tissue (Serrano et al. 1997). Induction of senescence by H-Ras is accompanied by increased expression of p53, p21 ${ }^{\text {cip1 }}$, and p16 Ink4a.

Ras proteins are membrane-associated GTPases that, in their GTP-bound state, transmit signal s into the interior of the cell. The signal is transmitted by several means, but prominent among these is a cascade of protein kinases initiated by the Raf-1 protein serine/threonine kinase (Avruch et al. 1994; M arshall 1996). Binding of Raf to activated Ras predisposes it to activation by other means that likely include phosphorylation by Srcfamily protein tyrosine kinases at key regulatory tyrosine residues (Y340 and Y341 in Raf-1; Marais et al. 1995). Then, activated Raf phosphorylates to activate the second kinase in the cascade (MEK), and this, in turn, phosphorylates to activate the p42/p44 MAP kinases, also known as ERK2 and ERK1, respectively (Marshall 1994). Activated MAP kinases are pleiotropic modulators of cell function that phosphorylate cytosolic, membrane-bound, and nuclear substrates including several transcription factors (T reisman 1996). Activation of this signaling pathway has been implicated both in normal proliferation and differentiation and in the aberrant proliferation observed in cancer cells.

The signaling from Ras through Raf prompted us to ask whether Raf itself could elicit senescence. Using a conditionally active version of Raf that can be activated by estrogen and its analogs (Samuels et al. 1993), we demonstrated that activation of Raf suffices to both arrest the proliferation of IMR-90 cells and elicit premature senescence. Raf-induced senescence is irreversible and accompanied by a consistent elevation in the expression of $\mathrm{p} 16^{\mathrm{Ink} 4 \mathrm{a}}$ and appears to have no obvious requirement for either p53 or p21 ${ }^{\mathrm{Cipl}}$. Moreover, p16 ${ }^{\text {Ink4a }}$ can itself elicit senescence when expressed ectopically in IM R-90 cells. The signal from Raf that el icits senescence is apparently transmitted through M EK because pharmacological inhibition of this enzyme prevents Raf-induced senescence. Consequently, we propose that the kinase cascade initiated by Raf is likely the major signaling pathway that mediates senescence in response to Ras and that $\mathrm{p} 16^{\text {Ink4a }}$ is likely an important mediator of this response.

\section{Results}

Isolation of IMR-90 cells expressing a conditional version of Raf

To achieve conditional activation of the Raf/MEK/M AP kinase cascade in IM R-90 human lung fibroblasts, we employed a previously described chimera in which the catalytic domain of human Raf-1 was fused to the hormone-binding domain of the human estrogen receptor (Samuels et al. 1993). To provide a marker for cell sorting, an enhanced version of green fluorescent protein (EGFP) was fused to the amino terminus of the chimera as illustrated in Figure $1 \mathrm{~A}$ and described previously (Woods et al. 1997). A variant was also created in which a pair of adjacent regul atory tyrosine resi dues (equivalent to Y 340 and Y 341 [YY] in full-length Raf-1) were mutated to aspartic acid [DD], leading to a 10-fold increase in the activity of Raf-1 as described previously (Woods et al. 1997). These chimeras are hereafter designated as GFP $\Delta$ Raf- $1_{[Y Y]}: E R$ and GFP $\Delta$ Raf- $1_{[D D]}: E R$, respectively. GFP $\Delta$ Raf-1:ER proteins have little or no kinase activity until activated with estrogen or its analogs such as 4-hydroxy-tamoxifen (4-HT), whereupon they rapidly activate downstream signaling pathways (Samuels et al. 1993). By use of a replication-deficient retroviral vector, GFP $\Delta$ Raf-1:ER proteins were expressed in IM R-90 cells that had reached 25-35 doublings. IM R-90 cells normally become senescent after 50-60 population doublings (Hayflick and Moorhead 1961). Pooled populations of infected cells were selected with puromycin and then sorted by FACS to obtain cells expressing equival ent levels of GFP $\Delta$ Raf-1:ER. As a control, a pooled population of IMR-90 cells infected with a retrovirus encoding only the puromycin-resistance gene was derived in parallel (Babe).

Activation of Raf kinase arrests the proliferation of IMR-90 cells

Treatment of exponentially proliferating IMR-90 cells expressing GFP $\Delta$ Raf-1:ER with 4-HT elicited pronounced morphological changes. Within $24 \mathrm{hr}$, the cells became more refractile and, after 2-4 days, most displayed an extended cell morphology with a spherical cell body. The cells remained adherent to the substratum and viable for at least 2 weeks after the addition of 4-HT (data not shown). The population density of the cells did not change, suggesting an arrest of proliferation, and no evidence of apoptosis was detected in these cultures. Both the [YY] and [DD] forms of GFP $\Delta$ Raf-1:ER elicited the same response, al though the latter required less 4-HT to elicit maximal effects than the former (Fig. 1B, cf. a-C with $\mathrm{d}-\mathrm{f}$ ); this difference presumably reflects the greater kinase activity of GFP $\Delta$ Raf- $1_{[D D]}$ :ER once activated (Woods et al. 1997).

Activation of GFP $\Delta$ Raf-1:ER arrested the proliferation of IM R-90 cells (Fig. 1C). IM R-90 cells infected with only the viral vector (Babe), and cells expressing the [YY] and [DD] forms of GFP $\Delta$ Raf-1:ER all proliferated at the same rate in the absence of 4-HT. Upon activation of GFP $\Delta$ Raf-1:ER with 4-HT, IM R-90 cells ceased proliferation within 2 days and failed to reach confluence. The arrest of proliferation was confirmed by BrdU labeling and FACscan analysis and by the incorporation of methyl- $\left[{ }^{3} \mathrm{H}\right]$ thymidine into DNA (Table 1 ; data not shown). Activation of GFP $\Delta$ Raf- $I_{[Y Y]}$ :ER reduced the 
A

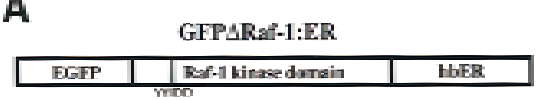

C

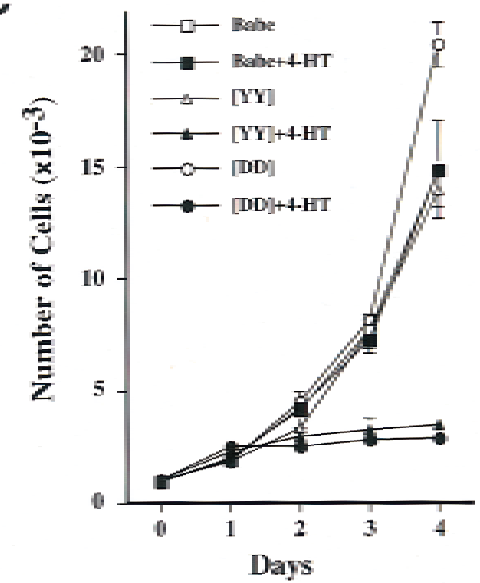

B
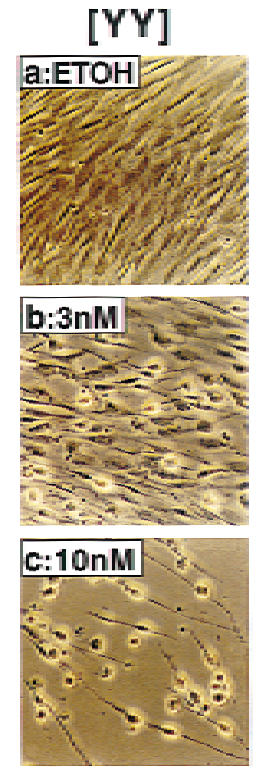

[DD]
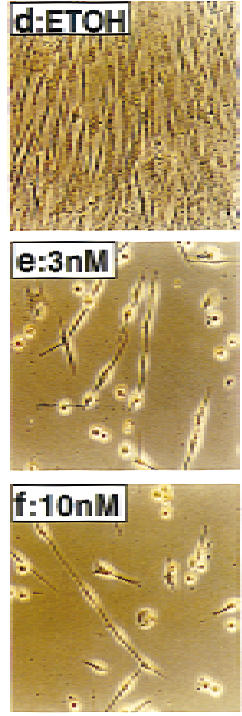

Figure 1. Activation of Raf kinase induces morphological alterations and arrests the proliferation of IMR-90 cells. (A) An inducible and tagged version of Raf. The illustrated construct was inserted into the replication-defective retrovirus described in $M$ aterials and Methods. (EGFP) Enhanced version of green fluorescent protein; (hbER) hormone-binding domain of the human estrogen receptor. The double vertical lines within the Raf- 1 kinase domain and YY/ DD below indicate the location of the tyrosine residues that were mutated to aspartic acid to generate the more active GFP $\Delta$ Raf$1_{\text {[DD] }}$ :ER as described in Materials and Methods and previously (Woods et al. 1997). (B) Morphological effects of Raf. IMR-90 cells expressing either the [YY] (ac) or [DD] (d-e) forms of GFP $\Delta$ Raf-1:ER were treated for 4 days with either ethanol as solvent control (ETOH) or different concentrations of 4-HT as indicated, then photographed with a phase-contrast microscope. (C) Proliferation of IMR-90 cells. Control (Babe) or GFP $\Delta$ Raf-1:ER-expressing IMR-90 cells ([YY] or [DD]) were cultured in DMEM containing $15 \%$ vol/vol FCS in the absence or presence of $100 \mathrm{~nm}$ 4-HT as indicated. Cells were harvested at daily intervals and counted with a hemocytometer. Each data point represents the average of four independent measurements. A graph representative of multiple experiments is presented. ( $\square$ ) Babe;

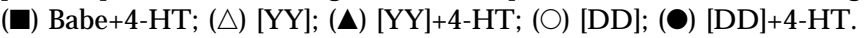

fraction of cells in S phase by one-third within 2 days and by about 10-fold within 4 days; similar results were obtained with GFP $\Delta$ Raf- $1_{[D D]}$ :ER, except that the reduction in cell proliferation occurred more rapidly and amounted to $>20$-fold at maximum. N either the proliferation nor the cell cycle profiles of control IMR-90 cells was affected by the addition of 4-HT (Fig. 1C; Table 1). We conclude that activation of Raf-1 arrests the cell cycle of normal human fibroblasts.

Table 1. Activation of GFP $\Delta$ Raf-1:ER induces cell cycle arrest

\begin{tabular}{lcrrrr}
\hline Cells & Days & $\begin{array}{r}4-\mathrm{HT} \\
(\mathrm{nM})\end{array}$ & $\begin{array}{c}\mathrm{G}_{1} \\
(\%)\end{array}$ & $\begin{array}{c}\mathrm{G}_{2} / \mathrm{M} \\
(\%)\end{array}$ & $\begin{array}{c}\mathrm{S} \\
(\%)\end{array}$ \\
\hline Babe & 2 & 0 & 41.0 & 13.9 & 45.1 \\
& 2 & 100 & 42.0 & 12.9 & 45.1 \\
& 4 & 0 & 33.8 & 8.4 & 57.9 \\
GFP & 4 & 100 & 33.5 & 8.4 & 58.0 \\
& 2 & 0 & 51.4 & 14.5 & 34.1 \\
GFPAR-1[YY]:ER & 2 & 100 & 57.9 & 19.1 & 23.0 \\
& 4 & 0 & 34.8 & 11.9 & 53.3 \\
& 4 & 100 & 69.4 & 25.3 & 5.4 \\
& 2 & 0 & 54.4 & 13.9 & 31.6 \\
& 2 & 100 & 62.6 & 25.7 & 11.6 \\
& 4 & 0 & 35.0 & 10.4 & 54.6 \\
& 4 & 100 & 67.8 & 30.2 & 2.0
\end{tabular}

Puromycin-resistant IM R-90 cells infected with control (Babe) and GFP $\Delta$ Raf-1:ER-encoding retroviruses were treated with 100 nM 4-HT for 2 or 4 days and labeled with $15 \mu \mathrm{m}$ BrdU for $3 \mathrm{hr}$. Ethanol-fixed cells were stained with FITC-anti-BrdU and with propidium iodide, and the percentage of cells in the different phases of the cell cycle was assessed by flow cytometry.
Senescence-associated, acidic $\beta$-galactosi dase activity in IMR-90 cells following Raf-1 activation

Given the effects of H-Ras on IM R-90 cells (Serrano et al. 1997), it seemed possible that activation of Raf might elicit senescence in these cells. Therefore, we tested the cells arrested by activated Raf for the presence of a se nescence-associated acidic $\beta$-galactosidase (SA- $\beta$-galactosidase) activity that has been associated with senescence in human cells (Dimri et al. 1995). Activation of GFP $\Delta$ Raf- $1_{[Y Y]}$ :ER in IM R-90 cells eli cited the expression of acidic $\beta$-gal actosi dase, which was apparent within 2-3 days and maximal by 5-6 days after addition of 4-HT (Fig. 2). We conclude that the arrest of proliferation induced by Raf is accompanied by senescence as the arrested cells remained viable for an extended period of time, assumed a characteristic morphology, and expressed an enzymatic marker that is strongly associated with cellular senescence.

\section{Expression of cell cycle regulatory proteins} in IMR-90 cells

Senescent cells typically contain el evated levels of the tumor suppressor protein p53 and the cell cycle inhibitors p16 ${ }^{\text {Ink4a }}$ and p21 ${ }^{\mathrm{Cip1}}$ ( $\mathrm{N}$ oda et al. 1994; Kulju and Lehman 1995; Alcorta et al. 1996; Hara et al. 1996). It is presumed that the increase in p53, in turn, augments transcription from the gene encoding p21 ${ }^{\mathrm{Cip1}}$ (El-Deiry et al. 1993); in contrast, the precise mechanism responsible for the induction of $16^{\text {Ink } 4 a}$ is not known but may involve transcriptional activation of the INK4A gene (Hara et al. 1996). Both $\mathrm{p} 16^{\mathrm{Ink} 4 \mathrm{a}}$ and $\mathrm{p} 21^{\mathrm{Cipl}}$ could contribute 


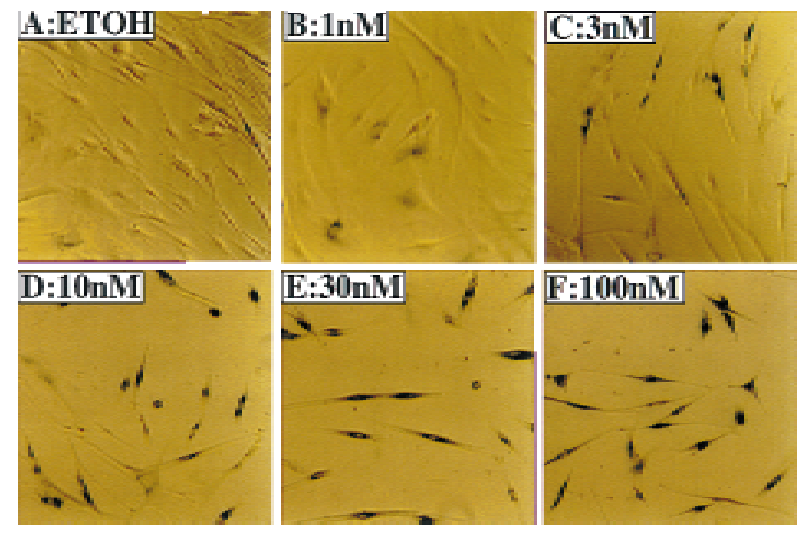

Figure 2. Activity of senescence-associated, acidic $\beta$-galactosidase in IMR-90 cells. Actively proliferating IMR-90 cells expressing GFP $\Delta$ Raf- $1_{[Y Y]}$ :ER were treated with either ethanol (ETOH) or with a range of 4-HT concentrations from 1-100 nM as indicated for 6 days, then stained to detect the activity of the senescence-associated, acidic $\beta$-gal actosidase.

to the arrest of cellular proliferation displayed by senescent cells (McConnell et al. 1998). Therefore, we examined the effect of GFP $\triangle$ Raf-1:ER activation on the expression of these proteins.

Activation of both the [YY] and [DD] forms of GFP $\Delta$ Raf-1:ER in IM R-90 cells led to induced expression of the chimeric protein, consistent with the selective stabilization of $\triangle$ Raf:ER fusion proteins that we observed in a variety of other cell types (Fig. 3A, left and middle panels; Samuels et al. 1993). No proteins cross-reactive with the anti-hbER antisera were detected in extracts from control IM R-90 cells (Babe; Fig. 3A, right panel). As observed in NIH-3T 3 cells, rapid activation of the p42/ p44 M AP kinases was observed by both Western blotting with phospho-specific antisera and by immune-complex kinase assays within $4 \mathrm{hr}$ following activation of GFP $\triangle$ Raf-1:ER. MAP kinase activation was maintained for up to 6 days after the addition of 4-HT (Samuels et al . 1993; data not shown).

Following activation of GFP $\Delta$ Raf-1:ER, we observed induction of cyclin D1 expression as well as induced expression of the CDK inhibitors p16 $6^{\text {Ink } 4 a}$ and p21 $1^{\text {Cip1 }}$ (Fig. 3B-D, left and middle panels). The extent and kinetics of induction of these proteins was more rapid in cells expressing the more active [DD] form of GFP $\Delta$ Raf1:ER compared to cells expressing the [YY] form of the protein, such that maximal levels of p16 ${ }^{1 n k 4 a}$ and p21 $1^{\text {Cip1 }}$ in particular were induced by the [DD] form after 8-16 hr whereas it required 32-48 hr of activity of the [YY] form to induce equivalent expression of these proteins.

In these experiments, Raf activation had little or no effect on the expression levels of either p53 (see Fig. 6A, below), $p 27^{\mathrm{Kip1}}$, or p42 MAP kinase the last of which serves as a convenient loading control for the Western bl ots presented in Figure 3 . In addition treatment of control IMR-90 cells (Babe) with 4-HT had no effect on the expression of cyclin D1, p16 ${ }^{\text {Ink4a }}$, p27 ${ }^{\text {Kip1 }}$, or p21 ${ }^{\mathrm{Cip1}}$ (Fig. 3 , right panels).

\section{Raf-induced cell cycle arrest is irreversible}

Cell cycle arrest and senescence induced in response to prolonged passage of cells in culture is invariably an irreversible phenomenon (Campisi 1996, 1997). Because Raf-induced cell cycle arrest in NIH-3T3 cells is fully reversed foll owing Raf inactivation (Samuels et al. 1993; Woods et al. 1997), we wished to determine whether the arrest and senescence phenotype observed in IMR-90
Figure 3. Effects of Raf on cell cycle regulators. Control (Babe) and GFP $\Delta$ Raf-1:ER ([YY]- and [DD])-expressing IMR-90 cells were rendered quiescent for $24 \mathrm{hr}$, at which time 4-HT was added to a final concentration of $1 \mu \mathrm{m}$. Cell extracts were prepared at different times (2-48 hr) after the addition of 4-HT, and the expression of GFP $\Delta$ Raf1:ER (A), p16 Ink4a $(B), p_{21}^{\text {Cipl }}(C)$, cyclin D1 (D), p27 ${ }^{\mathrm{Kipl}}(\mathrm{E})$, and p42 M AP kinase (F) was assessed by Western blotting with the appropriate antisera as described in M aterials and Methods. As a control, an equivalent volume of ethanol was added to the cells for $48 \mathrm{hr}\left(48^{-}\right)$.
A

GFPNRaf-1 $1_{[Y Y]}:$ ER

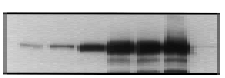

B

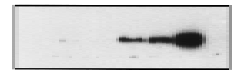

GFP $\triangle$ Raf-1 $1_{[D W}:$ ER
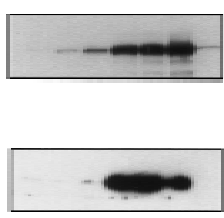

C

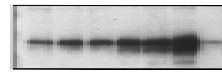

D

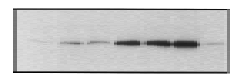

$\mathbf{E}$

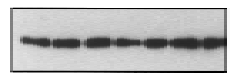

F
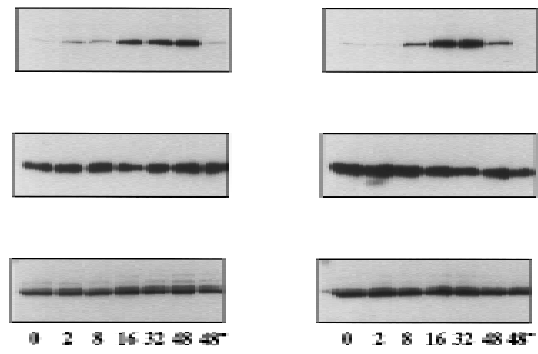

Babe
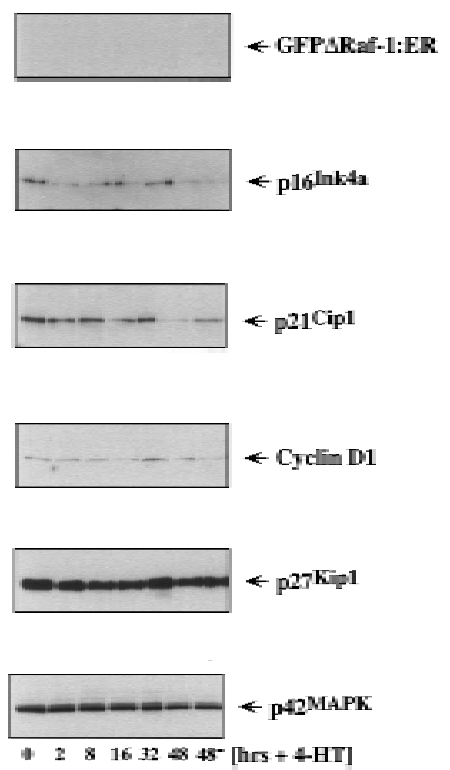
cells was irreversible. Control (Babe) and GFP $\Delta$ Raf-1:ER ([YY ] or [DD]) expressing IM R-90 cells were rendered quiescent in serum-free medium and then treated with either ethanol (solvent control) or 4-HT to activate GFP $\Delta$ Raf-1:ER for $24 \mathrm{hr}$. At this time, cells were either untreated or washed extensively to remove 4-HT (to inactivate GFP $\Delta$ Raf-1:ER) and then cultured in DMEM containing $10 \%$ FCS. The reentry of cells into S phase was monitored over the foll owing 6 days by the incorporation of $\left[{ }^{3} \mathrm{H}\right]$ thymidine into DNA.

Control (Babe) IM R-90 cells were unaffected by the addition of 4-HT to the culture media and proliferated as well as untreated cells (Fig. 4C). Cells expressing GFP $\Delta$ Raf-1:ER failed to re-enter the cell cycle when maintained in the continuous presence of $4-\mathrm{HT}$ (Fig. $4 A$,B) consistent with the ability of Raf to eli cit cell cycle arrest in these cells (Fig. 1). Interestingly, cells in which

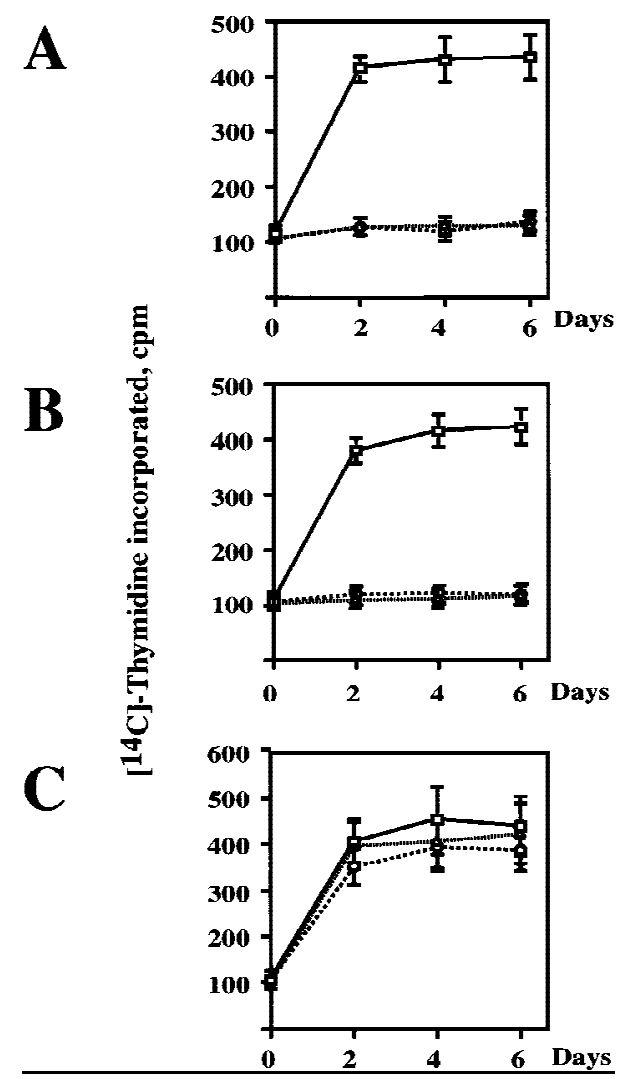

Figure 4. Raf-induced cell cycle arrest is irreversible. (A) GFP $\Delta$ Raf- $1_{[Y Y]}$ :ER- and (B) GFP $\Delta$ Raf-1 $1_{[D D]}$ :ER-expressing IMR90 cells and (C) control cells (Babe) plated on Cytostar T plates were rendered quiescent in serum-free medium in the absence or presence of $1 \mu \mathrm{m} 4-\mathrm{HT}$ for $24 \mathrm{hr}$. At that time cells in the absence of $4-\mathrm{HT}$ were stimulated with media containing $10 \%$ $\mathrm{vol} / \mathrm{vol}$ FCS. Cells in the presence of $4-\mathrm{HT}$ were either maintained in the continuous presence of 4-HT (4-HT continuous) or were washed extensively to remove the 4-HT (4-HT washed) prior to stimulation with media containing $10 \%$ vol/vol FCS. Cell proliferation was then measured over the following 6 days by the incorporation of methyl-[ $\left.{ }^{14} \mathrm{C}\right]$ thymidine into DN A. ( $\square$ ) $10 \%$ FCS; $(\triangle)$ 4-HT continuous; $(\bigcirc)$ 4-HT washed.

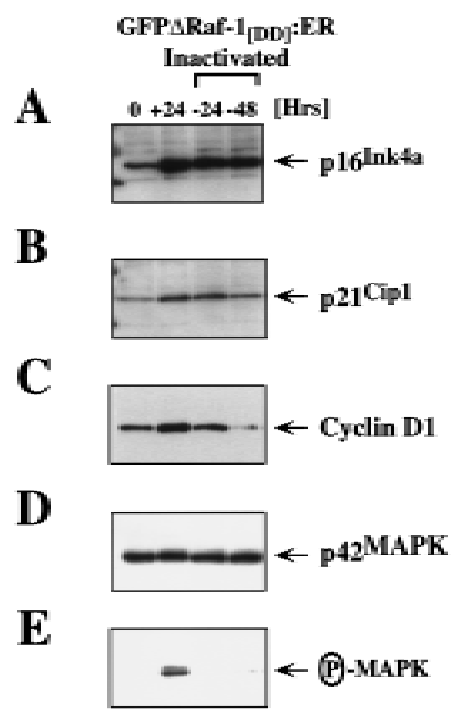

Figure 5. Sustained expression of $p 16^{\text {nk } 4 a}$ following inactivation of GFP $\Delta$ Raf-1:ER. IMR-90 cells expressing GFP $\Delta$ Raf$1_{[D D]}$ :ER were either untreated $(0)$ or treated with $1 \mu \mathrm{M} 4-\mathrm{HT}$ for $24 \mathrm{hr}$ (all other samples). After $24 \mathrm{hr}$ in $4-\mathrm{HT},(+24)$ cells were washed extensively and then cultured in the absence of 4-HT for a further $24(-24)$ or $48 \mathrm{hr}(-48)$. Cell extracts were prepared, and the expression of p16 Ink4a $(A), p 21^{\text {Cip1 }}(B)$, cyclin D1 (C), and p42 MAP kinase (D) and the activity of p42/p44 MAP kinases (E) was assessed by Western blotting with the appropriate antisera as described in $\mathrm{M}$ aterials and $\mathrm{M}$ ethods.

the GFP $\triangle$ Raf-1:ER was active for $24 \mathrm{hr}$ and then inactivated also failed to proliferate upon culture in media containing $10 \%$ FCS for up to 6 days after the inactivation of GFP $\Delta$ Raf-1:ER. These data indicate that Raf-induced cell cycle arrest in IM R-90 cells is irreversible.

To ensure that the inactivation of GFP $\Delta$ Raf-1:ER did indeed lead to the inactivation of the MAP kinase pathway, we repeated the experiment described above in larger scal e to analyze the effects of GFP $\Delta$ Raf-1:ER inactivation on the activity of the MAP kinases and the expression of cyclin D1, p21 ${ }^{\mathrm{Cip1}}$, and p16 ${ }^{\mathrm{Ink} 4 a}$. Consistent with previous observations, withdrawal of 4-HT from IM R-90 cells expressing activated GFP $\Delta$ Raf-1:ER led to the inactivation of the p42/p44 MAP kinases measured 24 or $48 \mathrm{hr}$ after 4-HT withdrawal as assessed with phospho-specific anti sera (P-M APK, Fig. 5E). Consistent with the inactivation of the MAP kinases, the levels of p21 ${ }^{\mathrm{Cip} 1}$ and cyclin D 1 expressi on declined to basal levels following removal of 4-HT (Fig. 5B,C). However, the level of expression of p16 ${ }^{\text {Ink4a }}$ did not decrease after GFP $\Delta$ Raf-1:ER inactivation, which may reflect the long half-life of both p16 ${ }^{\text {Ink4a }}$ mRNA and protein (Fig. 5A) (Hara et al. 1996). Equal loading of this Western blot was confirmed by reprobing with an antisera that recognizes p42 M AP kinase (Fig. 5D). These data indicate that continued GFP $\Delta$ Raf-1:ER activity is required for mai ntai ned expression of cyclin D1 and $\mathrm{p} 21^{\mathrm{Cipl}}$ but is not required for the maintained expression of $p 16^{\text {Ink4a. }}$ 


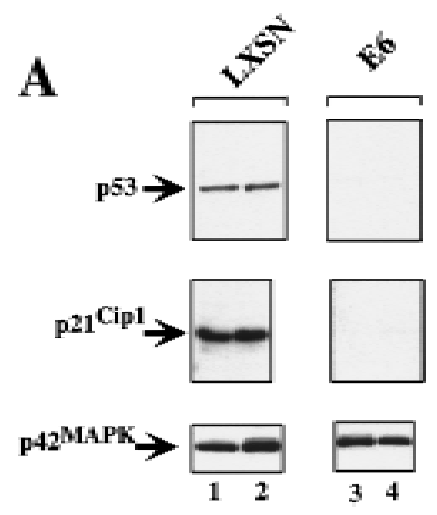

B

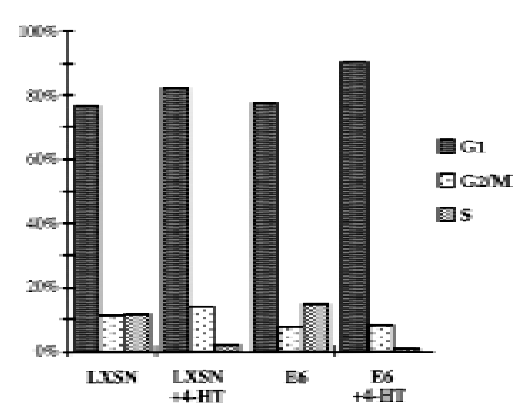

C
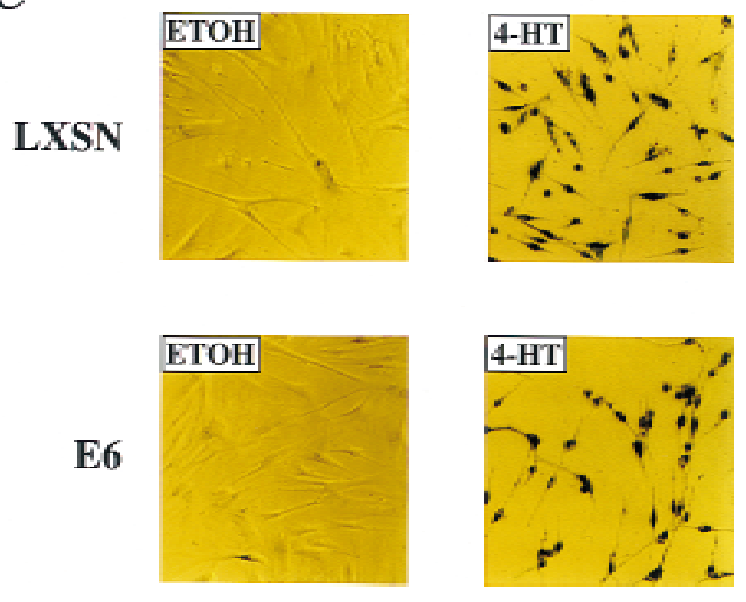

Neither p53 nor p21 ${ }^{\mathrm{Cip1}}$ is required for Raf-induced senescence in IMR-90 cells

Previous work has attributed the Raf-induced arrest of normal mouse embryo fibroblasts and primary rat Schwann cells to the induced expression of p21 Cip1, which, under some circumstances, is mediated by p53 (Lloyd et al. 1997; Woods et al. 1997). To determine whether there is a rol efor $\mathrm{p} 53$ and $\mathrm{p} 21^{\mathrm{Cip} 1}$ in Raf-induced cell cycle arrest and senescence, we used a second retrovirus vector to express the E6 oncoprotein of HPV16 in IMR-90 cells already expressing the [YY] form of GFP $\Delta$ Raf-1:ER. Because E6 binds to p53 and facilitates its destruction by ubiquitin-mediated proteolysis, we anticipated that the expression of both p53 and p21 ${ }^{\mathrm{Cip1}}$
Figure 6. Raf-induced cell cycle arrest and senescence of IM R90 cells in the absence of detectable p53 and p21 ${ }^{\mathrm{Cip1}}$. (A) Effect of the E6 oncoprotein on p53 and p21 ${ }^{\mathrm{Cip} 1}$ expression. IMR-90 cells expressing GFP $\Delta$ Raf- $1_{[Y Y]}$ :ER cells were infected with retroviruses encoding resistance to neomycin al one (LXSN) or expressing the E6 protein of HPV16 and resistance to neomycin (E6), and pooled populations of drug-resistant clones were established. Cells were then treated for $24 \mathrm{hr}$ with either ethanol (lanes 1,3) or 1 MM 4-HT (lanes 2,4). Cell lysates were prepared, and the expression of p53, p21 ${ }^{\mathrm{Cip1}}$, and p42 MAP kinase was assessed by Western blotting with the appropriate antisera. (B) Raf-induced cell cycle arrest is unaffected by expression of HPV16 E6 protein. IM R-90 cell populations described above expressing GFP $\Delta$ Raf- $1_{[Y Y]}$ :ER in the absence (LXSN) or presence of the HPV16 E6 oncoprotein (E6) were treated with either ethanol or 4-HT for 4 days. Cells were labeled with BrdU for $3 \mathrm{hr}$ prior to harvest, fixed, and stained with a FITC-conjugated anti-BrdU antibody and propidium iodide to detect S-phase cells. Cells were analyzed by use of a Becton-Dickinson FACscan to determine the percentage of cells in the $G_{1}, S$, and $G_{2} / M$ phases of the cell cycle. (C) Raf-induced SA- $\beta$-galactosidase activity. IMR-90 cell populations described above expressing GFP $\Delta$ Raf$1_{[Y Y]}$ ER in the absence (LXSN) or presence of the HPV16 E6 oncoprotein (E6) cells were treated with either ethanol or 4-HT for 6 days at which time the activity of SA- $\beta$-galactosidase was assessed as described in Materials and M ethods.

would be largely extinguished in these cells (Scheffner et al. 1990). As a control, we infected the same cells with a retrovirus encoding resistance to $\mathrm{N}$ eo al one (LXSN). Expression of HPV16 E6 in IM R-90 cells reduced both p53 and $\mathrm{p} 21^{\mathrm{Cip1}}$ to below detectable levels, and activation of GFP $\triangle$ Raf-1:ER had no effect on the expression of either of these proteins (Fig. 6A, E6). The expression of p53 and p21 ${ }^{\mathrm{Cip} 1}$ was readily detected in the control IMR-90 cell population (Fig. 6A, LXSN).

Activation of GFP $\triangle$ Raf- $1_{[Y Y]}$ :ER in the absence of detectable $\mathrm{p} 53$ and $\mathrm{p} 21^{\mathrm{Cip1}}$ reduced the fraction of cells in $\mathrm{S}$ phase by 5- to 10-fold, similar to the response of cells that were not expressing E6 (Fig. 6B, LXSN and E6). Similar conclusions were reached by measurement of incorporation of methyl- $\left[{ }^{14} \mathrm{C}\right]$ thymidine into DNA (data not shown). M oreover, cells lacking p53 and p21 ${ }^{\mathrm{Cip1}}$ developed the SA- $\beta$-gal actosidase marker of senescence and the characteristic cell morphology that is described above (Fig. 6C). We conclude that Raf-induced alterations in cell morphology, prol iferative arrest, and senescence in IM R-90 cells do not require the action of either p53 or p21 ${ }^{\mathrm{Cip1}}$.

\section{Overexpression of $\mathrm{p} 16^{\text {nk } 4 \mathrm{a}}$ elicits senescence}

To explore the ability of $\mathrm{p} 16^{\text {Ink } 4 \mathrm{a}}$ to induce senescence in cells, we infected parental IM R-90 cel Is with a retrovi rus engi neered to constitutively express $\mathrm{p} 16^{1 \mathrm{nk}} 4 \mathrm{a}$. Consistent with previous observations (McConnell et al. 1998), IM R-90 cells expressing p16 Ink4a became positive for SA$\beta$-galactosi dase activity (Fig. 7A) whereas cells infected with a control retrovirus were negative. FACscan analysis reveal ed a threefold reduction in S-phase cells compared with the control infected populations (43\% vs. 
13.9\%; Fig. 7B). We conclude that the sustained overexpression of $\mathrm{p} 16^{\mathrm{Ink} 4 \mathrm{a}}$ can arrest proliferation and elicit senescence in normal human fibroblasts and may be sufficient to explain the induction of senescence by Raf.

Inhibition of the MAP kinase cascade blocks the induction of senescence by Raf

Signaling by Raf is executed, at least in part, through the MEK/M AP kinase pathway (Marshall 1994; Samuels et al. 1993). Therefore, we sought to impl icate this enzyme cascade in Raf-induced cell cycle arrest and senescence by using PD 098059 (PD), a specific and sel ective inhibitor of MEK1 (Alessi et al. 1995). As described above, activation of GFP $\Delta$ Raf- $1_{[Y Y]}:$ ER led to the phosphorylation and activation of the p42/p44 MAP kinases (Fig. 8A). In the presence of $\mathrm{PD}$, however, phosphorylation of the MAP kinases was reduced to levels comparable to those found in uninduced IM R-90 cells (Fig. 8A, cf. 4-HT with 4-HT +PD). Furthermore, the basal levels of MAP kinase phosphorylation in the absence of Raf activation were also reduced following treatment of cells with PD (Fig. $8 \mathrm{~A}$, cf. ETOH with PD). The levels of p16 ${ }^{\text {Ink4a }}$ mirrored the phosphorylation of the MAP kinases (Fig. 8A), as if
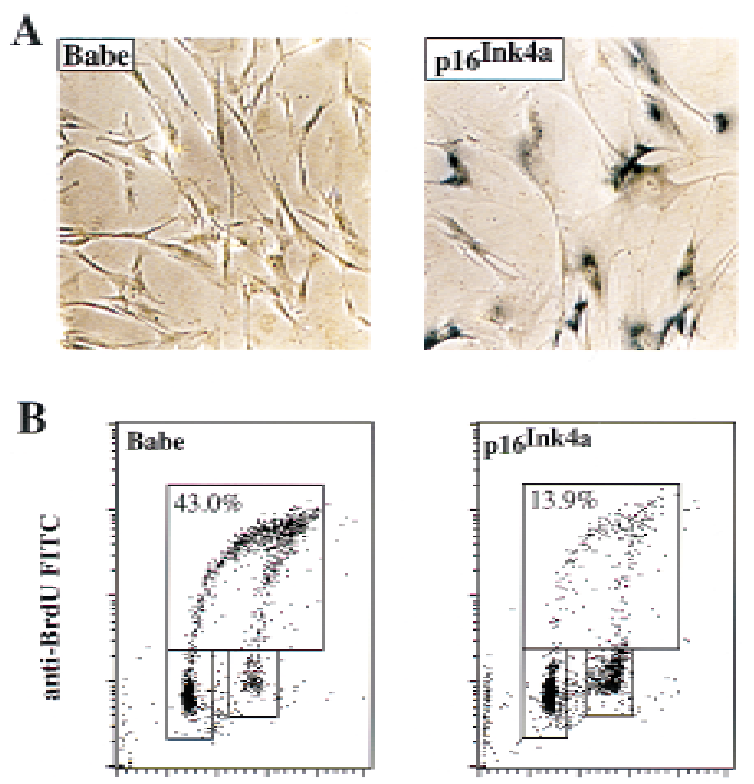

Propidium lodide $\longrightarrow$

Figure 7. Cell cycle arrest and induction of senescence by p16 Ink4a. IMR-90 cells were infected with a retroviral vector expressing either the selectable marker for puromycin resistance al one (Babe) or the marker plus human p16 ${ }^{\text {Ink4a }}$ as indicated. The infected cells were then subjected to selection for 6 days. Surviving cells were analyzed for SA- $\beta$-galactosidase activity (A) or labeled with BrdU for analysis by FACscan for relative content of DNA (B). (B) U pper boxes delineate cells in $S$ phase; lower boxes delineate cells in $G_{0} / G_{1}$ (left) or $G_{2} / M$ (right). $\mathrm{N}$ umbers in upper boxes indicate percentage of cells in $\mathrm{S}$ phase.
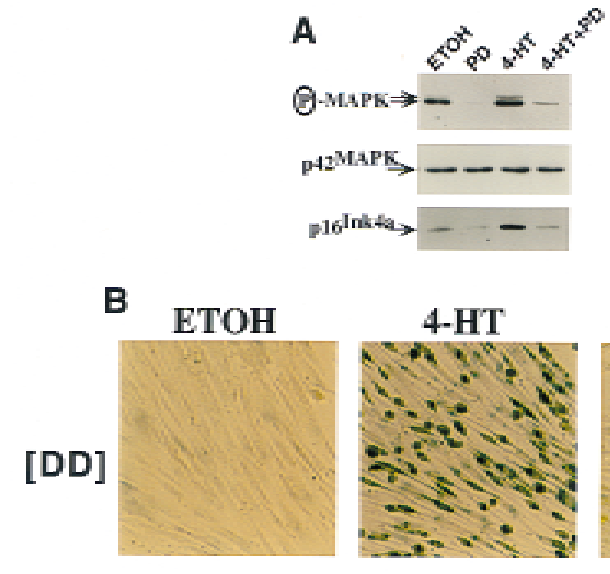

4-HT+PD
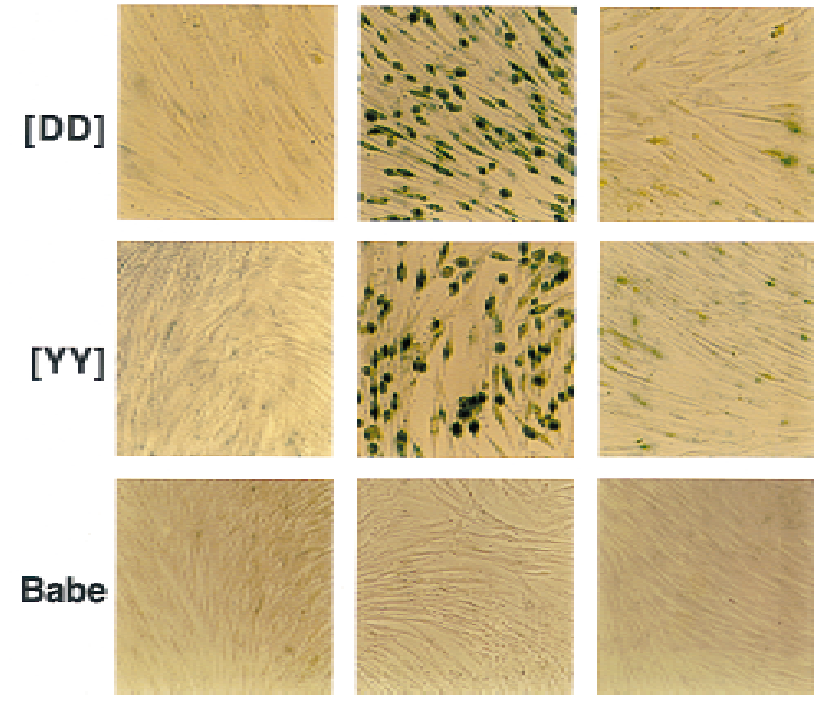

Figure 8. MEK activity is required for induction of $\mathrm{p} 16^{\mathrm{Ink} 4 a}$ and senescence by Raf in IM R-90 cells. (A) Inhibition of M AP kinase activation and p16 ${ }^{\text {Ink4a }}$ expression by PD098059. Asynchronously growing IM R-90 cells expressing GFP $\Delta$ Raf- $1_{[Y Y}$ ]: ER were treated with either $10 \mathrm{~nm} 4-\mathrm{HT}$ or an equivalent volume of ethanol (ETOH) for 4 days in the absence (DMSO) or presence of the MEK inhibitor PD098059 (PD, $25 \mu \mathrm{M}$ ) as indicated. The activity of p42/p44 MAP kinase and the expression of p42 MAP kinase and $\mathrm{p} 16^{\text {Ink4a }}$ were assessed by Western blotting with the appropriate antisera. (B) MEK activity is required for Raf-induced senescence in IM R-90 cells. Control (Babe) and GFP $\Delta$ Raf1:ER ([YY]- and [DD ])-expressing IM R-90 cells were treated with various combinations of 4-HT (10 nM for [DD] and $3 \mathrm{~nm}$ for $[Y Y]), P D(25 \mu \mathrm{M})$, or an equival ent volume of ethanol or DM SO for 6 days, and stained for SA- $\beta$-galactosidase activity.

one or more of the MAP kinases might control the expression of $\mathrm{p} 16^{\mathrm{Ink} 4 \mathrm{a}}$.

N ext we assessed the effect of PD on cellular proliferation. In the absence of activated Raf, inhibition of the MAP kinases reduced the fraction of cells in S phase by sixfold (Table 2). This result was in accord with the elimination of MAP kinase phosphorylation described above and with previous results (Alessi et al. 1995). When Raf was activated, however, the presence of PD largely prevented the inhibition of proliferation that would otherwise occur (Table 2). These results suggest that cell cycle arrest elicited by Raf is mediated by the MEK/MAP kinase cascade.

The presence of PD also prevented the appearance of $S A-\beta$-gal actosi dase activity and the antici pated morphological changes in response to the activation of GFP $\Delta$ Raf- 
Table 2. Prevention of Raf-induced arrest by inhibition of MEK

\begin{tabular}{lrcccr}
\hline Cells & $\begin{array}{r}4-\mathrm{HT} \\
(\mathrm{nM})\end{array}$ & $\begin{array}{c}\mathrm{PD} 98059 \\
(\mu \mathrm{M})\end{array}$ & $\begin{array}{c}\mathrm{G}_{1} \\
(\%)\end{array}$ & $\begin{array}{c}\mathrm{G}_{2} / \mathrm{M} \\
(\%)\end{array}$ & $\begin{array}{c}\mathrm{S} \\
(\%)\end{array}$ \\
\hline Babe & 0 & 0 & 40.9 & 17.7 & 41.4 \\
& 10 & 0 & 40.2 & 17.1 & 42.7 \\
GFP Raf-1[YY]:ER & 10 & 25 & 67.1 & 26.0 & 6.9 \\
& 0 & 0 & 40.9 & 13.4 & 45.7 \\
& 10 & 0 & 68.6 & 24.5 & 6.8 \\
& 10 & 25 & 50.4 & 16.1 & 33.5 \\
\hline
\end{tabular}

Control (Babe) and GFP $\Delta$ Raf-1 $1_{[Y Y}$ :ER-expressing IMR-90 cells were treated with $10 \mathrm{~nm} 4-\mathrm{HT}$ in the absence or presence of 25 $\mu \mathrm{M}$ of the MEK inhibitor PD 098059 for 4 days and labeled with $15 \mu \mathrm{M} \mathrm{BrdU}$ for $3 \mathrm{hr}$. Ethanol-fixed cells were stained with FITCanti-BrdU and with propidium iodide; and the percentage of cells in the different phases of the cell cycle was assessed by flow cytometry.

1:ER (Fig. 8B). The blockade was effective against both GFP $\Delta$ Raf- $1_{[Y Y]}$ :ER and GFP $\Delta$ Raf- $1_{[D D]}$ :ER induced with optimal concentrations of 4-HT. N either 4-HT al one nor 4-HT in combination with PD had any morphological effect on the puromycin-resistant control IM R-90 cell population (Fig. 8B, Babe). Therefore, we conclude that activation of MEK is required for the arrest of proliferation and the induction of senescence triggered by Raf in IMR-90 cells. The results also reveal a pleiotropic response to M AP kinase activity that is dose dependent. As observed previously, there is an optima of activity that permits cellular proliferation (Woods et al. 1997). Either a deficit or a surfeit of the activity leads to cell cycle arrest, but only a surfeit elicits senescence.

\section{Discussion}

Activation of Raf elicits senescence in human fibroblasts

Previous work has indicated that Ras and Raf oncoproteins can elicit cell cycle arrest in both primary and immortalized cells (Lloyd et al. 1997; Woods et al. 1997). In the IMR-90 strain of human fibroblasts, Ras oncoproteins can elicit premature senescence (Serrano et al. 1997). Here we show that activation of Raf has a similar effect. Using a complementary approach with constitutively active forms of Ras and MEK, others have reached similar conclusions (Lin et al. 1998). The phenotypic response of IM R-90 cells to Raf displays many of the hallmarks of senescence: irreversible withdrawal from the cell division cycle; assumption of a characteristic morphology; retention of viability; and induction of an enzymatic marker for senescence, acidic $\beta$-galactosidase. However, a number of interesting differences were observed between the senescent phenotype elicited by Raf and that induced either by Ras or by prolonged passage in culture. Senescent cells are typically arrested in the $G_{1}$ phase of the cell cycle (Hayflick and Moorhead 1961; Campisi 1996, 1997). In contrast, only a portion of IMR90 cells rendered senescent by Raf are arrested in $G_{1}$; the remainder appear to be in $\mathrm{G}_{2} / \mathrm{M}$. In addition, Ras-induced senescence is characterized by a distinctive flattened cell phenotype that is in marked contrast to the rounded, refractile morphology of IM R-90 cells rendered senescent by Raf. This distinction may reflect the ability of Ras to influence pathways in addition to those activated by Raf such as PI3' kinase, Ral-GDS (guaninenucleotide dissociation stimulator), and members of the Rho family of GTPases that are known to play an integral role in the control of cell shape. Such differences between the effects of Ras and Raf on cell morphology have been observed in primary rat cardiac myocytes and bear further examination (Thorburn et al. 1994).

Senescent cells typically express high levels of p53, p21 ${ }^{\text {Cip1 }}$, and p16 ${ }^{\text {Ink4a }}$ (Zindy et al. 1997; Reznikoff et al. 1996; McConnell et al. 1998). Previous work has indicated that, in rodent cells, p21 $1^{\mathrm{Cip} 1}$ is a major mediator of cell cycle arrest in response to either H-Ras or Raf (Lloyd et al. 1997; Woods et al. 1997). For example, Raf cannot arrest proliferation in mouse fibroblasts that are deficient in $\mathrm{p} 21^{\mathrm{Cipl}}$, whereas it arrests both primary and immortalized cells that lack p16 ${ }^{\text {Ink4a }}(D$. Woods and $M$. McMahon, unpubl.). Furthermore, $T$ antigen, a dominant-negative allele of p53, and expression of antisense p21 ${ }^{\text {Cipl }}$ RNA (all of which impede the expression of p21 ${ }^{\mathrm{Cip} 1}$ ) prevented Raf induced cell cycle arrest in primary rat Schwann cells (Lloyd et al. 1997). In contrast, p21 ${ }^{\text {Cipl }}$ appears to be much less prominent in the re sponse of IMR-90 cells to either Ras or Raf. First, Raf consistently induced high levels of p16 Ink4a in IMR-90 cells, but did not induce high levels of either p53 or $\mathrm{p} 21^{\mathrm{Cip} 1}$. Indeed there was no detectable induction of p53, and the induction of $\mathrm{p} 21^{\mathrm{Cipl}}$ showed significant experimental variation. Second, a dominant-negative allele of p53 fail ed to block the senescent response to $\mathrm{H}$-Ras (data not shown). Third, Raf efficiently elicited cell cycle arrest and senescence in IMR-90 cells in which the levels of $\mathrm{p} 53$ and $\mathrm{p} 21^{\mathrm{Cipl}}$ were greatly reduced by the action of the E6 oncoprotein of HPV16.

Previous evidence suggested a role for $\mathrm{p} 16^{\mathrm{Ink} 4 \mathrm{a}}$ in the genesis of cellular senescence: The protein accumulates to high levels as cells approach senescence, and in many lines of cells that have escaped senescence, the INK4A gene is either defective, del eted, or inactivated by hypermethylation (Merlo et al. 1995; Reznikoff et al. 1996; Serrano et al. 1996; Foulkes et al. 1997; Loughran et al. 1997). The results described here add to that evidence by implicating $\mathrm{p} 16^{\text {Ink4a }}$ in the senescence induced by Raf in IM R-90 cells. First, induction by Raf produces a substantial rise in $\mathrm{p} 16^{\mathrm{Ink} 4 \mathrm{a}}$ that is coincident with the onset of cell cycle arrest and precedes the onset of senescence. Moreover, the irreversible nature of Raf-induced senescence is reflected by the fact that $\mathrm{p} 16^{\operatorname{lnk} 4 a}$ levels remain elevated even after the inactivation of the signal from Raf. Finally, the ectopic overexpression of p16 ${ }^{\text {Ink } 4 a}$ is itself sufficient to elicit proliferative arrest and senescence in IM R-90 cells.

The locus that encodes $\mathrm{p} 16^{\text {Ink4a }}$ also encodes a second protein known as p19ARF. These two proteins share a common second exon but are entirely distinct in their 
amino acid sequences (Quelle et al. 1995). The belated discovery of the tumor suppressor properties of p19ARF have, at least temporarily, obscured the role of p16 ${ }^{\text {Ink } 4 a}$ in both normal cellular processes and tumorigenesis (Kamijo et al. 1997; Pomerantz et al. 1998; Zhang et al. 1998). Our results demonstrate that p16 $6^{\text {Ink4a }}$ itself can elicit senescence in human fibroblasts, but do not speak to the biological activities of p19ARF. $N$ or do our results address a possible role for other members of the IN K4 family of CDK inhibitors. It is clear however that p16 $6^{\text {Ink } 4 a}$ is not unique amongst the CDK inhibitors in its ability to induce senescence in cells. Ectopic expression of $\mathrm{p} 15^{\mathrm{Ink} 4 \mathrm{~b}}, \mathrm{p} 21^{\mathrm{Cip} 1}$, and $\mathrm{p} 27^{\mathrm{Kipl}}$ elicited proliferative arrest, senescence, and SA- $\beta$-gal activity in TIG-3 primary human fibroblasts (McConnell et al. 1998). It seems likely that the inhibition of cyclin-CDK complexes by such inhibitors triggers a senescence program of which the mechanism remains poorly defined.

The phenotypic response to Raf is determined by signal strength

Previous reports have indicated that the same intracelIular signaling pathway can elicit different phenotypic outcomes, determined by the relative strength of that signal (Marshall 1995; Woods et al. 1997). The results presented here reveal a plei otropic response to Raf activation that is similarly dose dependent. In normal proliferating cells Raf/MEK/MAP kinase activity is presumably maintained by the presence of external growth factors (Fig. 8A). Interruption of the signal from MEK to MAP kinase (with PD) arrests cellular proliferation; thus, MAP kinase activity is required for initiation and maintenance of the cell division cycle, as reported previously (Alessi et al. 1995). In contrast, activation of oncogenic Raf gave rise to a sustained el evation of MAP kinase activity, resulting in both the arrest of cell division and senescence. In this latter setting, reduction of MAP kinase activity to moderate levels with PD all owed the cells to continue proliferating (Fig. 8A; Table 2).

The dose-dependent response to Raf/MEK/MAP kinase activation may be explained, at least in part, by the differential sensitivity of cyclin D1 and p16 $6^{\text {Ink } 4 a}$ expression to activation of the MAP kinase pathway. Both in this study (Fig. 4D) and in a previously published report (Woods et al. 1997), cyclin D1 accumulation, which serves to promote cell cycle progression, appears to be activated more rapi dly and in response to lower levels of signaling through the MAP kinase pathway compared with the CDK inhibitors $p 21^{\mathrm{Cip1}}$ and p16 $6^{\text {Ink4a }}$, which appear to require a stronger signal sustained over a prolonged period of time. However, once this latter threshold is breached, it is likely that the induced p16 nk4a inhibits cdk4 even in the presence of el evated cyclin D1 (Fig. 3B,D). It is not immediately apparent why p16 $6^{\text {Ink } 4 a}$ induction is accompanied by other manifestations of senescence, although it is possible that inhibition of E2F transcription factors, as a consequence of $\mathrm{Rb}$ hypophosphorylation, may be involved in modulating aspects of the senescence phenotype. It will ultimately be of con- siderable interest to dissect the biochemical pathways that lead from the activation of Raf to the induced expression of $\mathrm{p} 16^{\mathrm{Ink} 4 \mathrm{a}}$ and to determine whether these signaling pathways play a more general role in the induction of senescence in other contexts such as in response to prolonged passage in culture or to alterations in the properties of telomeres (van Steensel et al. 1998).

It is now well established that both qualitative and quantitative aspects of Raf/M EK/M AP kinase activation play a crucial role in determining the biological outcome of signaling through this pathway. In both human and mouse cells, depending on the level of activation, the MAP kinase pathway can be employed to elicit strikingly different biological outcomes, namely cell proliferation, cell cycle arrest, terminal differentiation, and senescence (Lloyd et al. 1997; Woods et al. 1997). The biochemical mechanisms underlying these disparate observations require further elucidation. Whatever its mechanism, induction of senescence could provide a defense against neoplastic transformation when Ras, Raf, or the downstream MAP kinase cascade is inappropriately active. In this regard, senescence may be an alternative to apoptosis as a defense against tumorigenesis (Campisi 1996, 1997; Serrano et al. 1997).

\section{Materials and methods}

\section{Cell culture and virus infection}

IM R-90 cells were obtained from the American Tissue Culture Collection and propagated either in phenol red-free MEM or DMEM as described previously (Samuels et al. 1993). Retrovirus vectors for the expression of GFP $\Delta$ Raf-1:ER and resistance to puromycin have been described previously (Morgenstern and Land 1990; Woods et al. 1997). A cDNA encoding human p16 ${ }^{\text {Ink4a }}$ was subcloned into the pBabe retroviral vector that carries puromycin resistance as a selectable marker (M orgenstern and Land 1990). The E6 oncogene of HPV16 was subcloned into the LXSN retroviral vector, which also encodes resistance to neomycin as a selectable marker (Miller and Rosman 1989).

By use of a calcium phosphate protocol, retroviral vectors were packaged in the Phoenix A cell line from G. N olan (Stanford University, CA) producing nonreplicating forms of amphotrophic virus (Pear et al. 1993; Kinsella and N olan 1996). IM R-90 cells were infected with viral supernatants as described previously (Samuels et al. 1993). Pooled populations of drugresistant cells expressing equivalent levels of GFP $\Delta$ Raf-1:ER were isolated by FACs (Woods et al. 1997).

The proliferative capacity of cells was monitored by seeding of $\sim 1000$ cells in $12-\mathrm{mm}$ diameter wells in MEM containing $15 \% \mathrm{vol} / \mathrm{vol}$ fetal calf serum (FCS). 4-HT in ethanol or an equivalent volume of ethanol was added the next day. Cells were harvested by trypsination at intervals of $24 \mathrm{hr}$, stained with $0.1 \%$ trypan blue, and viable cells enumerated by use of a hemocytometer. Four wells of cells were counted separately and the results averaged. Cells were stained for the activity of the SA- $\beta$-galactosidase as described previously (Dimri et al. 1995).

DNA synthesis in IMR-90 cells was measured by plating of cells in Cytostar-T 96-well scintillating microplates and labeling with methyl- $\left[{ }^{14} \mathrm{C}\right]$ thymidine according to the manufacturer's instructions (Amersham Life Science). Incorporation of methyl- $\left[{ }^{14} \mathrm{C}\right]$ thymidine was estimated by use of a Packard top- 
count scintillation machine as described previously (Woods et al. 1997).

\section{Analysis of cell extracts by Western blotting}

Cell extracts were prepared in ELB Iysis buffer (50 mM HEPES at $\mathrm{pH} 7.0,150 \mathrm{~mm} \mathrm{NaCl}$, and $0.1 \%$ (vol/vol, N P-40) containing a standard cocktail of protease and phosphatase inhibitors (Samuels et al. 1993). Aliquots $(50 \mu \mathrm{g})$ of cell extract, separated by polyacrylamide gel electrophoresis, were analyzed by probing of Western blots with the appropriate antisera. Mouse monoclonal and rabbit polyclonal antibodies reactive against human proteins were as follows: monoclonal anti-p21 ${ }^{\mathrm{Cip1}}$ (Ab-1, Calbiochem); monoclonal anti-p16 $6^{\text {Ink4a }}$ (Ab-1 and Ab-2, NeoMarkers); monoclonal anti-p53 (Mixture of DO.1, Santa Cruz Biotechnology and Ab-1, Calbiochem); monoclonal anti-p27 Kip1 (Clone 57, Transduction Labs); polyclonal anti-Erk2 (C14, Santa Cruz Biotechnology); polyclonal anti-hbER (HC-20, Santa Cruz Biotechnology); polyclonal anti-cyclin D1 (gift of Dave Parry and Emma Lees, DNAX), and polyclonal phosphospecific antip42/p44 M AP kinase (Thr-202/Tyr-204, N ew England Biolabs). Horseradish peroxidase-conjugated anti-mouse and anti-rabbit immunogl obulins were from Amersham and used at a dilution of 1: 5000 . Western blots were developed with the SuperSignal ULTRA chemiluminescence detection kit (Pierce).

\section{Analysis of IMR-90 cell cycle phase by BrdU labeling}

Cells were replated bel ow confluence 1 day prior to analysis for optimal cell cycle distribution and were labeled with BrdU (15 $\mu \mathrm{M}) 3 \mathrm{hr}$ prior to harvest. Single nuclei suspensions derived from ethanol-fixed cells were washed and costained with an antiBrdU-FITC conjugated antibody (Boehringer $M$ annhei $\mathrm{m}$ ) and 20 $\mu \mathrm{g} / \mathrm{ml}$ propidium iodide prior to analysis with a Becton-Dickinson FACscan as described previously (Takagi et al. 1993).

\section{Acknowledgments}

We thank the members of the M cM ahon and Bishop laboratories for useful comments and suggestions. We are particularly grateful to Emma Lees and Dave Parry for the provision of antisera and for stimulating discussion. We thank Scott Lowe for communicating results prior to publication, Liang Zhu for the provision of the $p 16^{\text {Ink4a }} \mathrm{CDNA}$, and Ken Aldape for assistance with FACscan analysis. We are grateful for the support of Gwen Jewell, Gary Burget, and M aribel Andonian in the preparation of the manuscript and figures. Work here was supported by the N ational Institutes of Health (CA 44338-12) and by funds from the G.W. Hooper Foundation. DNAX Research Institute is supported by Schering Plough Corporation.

The publication costs of this article were defrayed in part by payment of page charges. This article must therefore be hereby marked 'advertisement' in accordance with 18 USC section 1734 solely to indicate this fact.

\section{References}

Alcorta, D.A., Y. Xiong, D. Phelps, G. Hannon, D. Beach, and J.C. Barrett. 1996. Involvement of the cyclin-dependent kinase inhibitor p16 (Ink4a) in replicative senescence of normal human fibroblasts. Proc. Natl. Acad. Sci. 93: 1374213747.

Alessi, D.R., A. Cuenda, P. Cohen, D.T. Dudley, and A.R. Saltiel. 1995. PD 098059 is a specific inhibitor of the activation of mitogen-activated protein kinase kinase in vitro and in vivo. J. Biol. Chem. 270: 27489-27494.

Avruch, J., X.F. Zhang, and J.M. Kyriakis. 1994. Raf meets Ras: Completing the framework of a signal transduction pathway. Trends Biochem Sci. 19: 279-283.

Bodnar, A.G., M. Ouellette, M. Frolkis, S.E. Holt, C.P. Chiu, G.B. Morin, C.B. Harley, J.W. Shay, S. Lichtsteiner, and W.E. Wright. 1998. Extension of life-span by introduction of tel omerase into normal human cells. Science 279: 349-352.

Brown, J.P., W. Wei, and J.M. Sedivy. 1997. Bypass of senescence after disruption of p21CIP1/WAF1 gene in normal diploid human fibroblasts. Science 277: 831-834.

Campisi, J. 1996. Replicative senescence: An old lives' tal e? Cell 84: 497-500.

- - 1997. The biology of replicative senescence. Eur. J. Cancer 33: 703-709.

Dimri, G.P., X. Lee, G. Basile, M. A costa, G. Scott, C. Roskelley, E.E. M edrano, M. Linskens, I. Rubelj, O. Pereira-Smith et al. 1995. A biomarker that identifies senescent human cells in culture and in aging skin in vivo. Proc. Natl. Acad. Sci. 92: 9363-9367.

El-Deiry, W.S., T. Tokino, V.E. Velculescu, D.B. Levy, R. Parsons, J.M. Trent, D. Lin, W.E. Mercer, K.W. Kinzler, and B. Vogelstein. 1993. WAF1, a potential mediator of p53 tumor suppression. Cell 75: 817-825.

Foulkes, W.D., T.Y. Flanders, P.M. Pollock, and N.K. Hayward. 1997. The CDKN 2A (p16) gene and human cancer. Mol. Med. 3: 5-20.

Hainaut, P., T. Soussi, B. Shomer, M. Hollstein, M. Greenblatt, E. Hovig, C.C. Harris, and R. M ontesano. 1997. Database of p53 gene somatic mutations in human tumors and cell lines: Updated compilation and future prospects. Nucleic Acids Res. 25: 151-157.

Hall, M. and G. Peters. 1996. Genetic alterations of cyclins, cyclin-dependent kinases, and Cdk inhibitors in human cancer. Adv. Cancer Res. 68: 67-108.

Hara, E., R. Smith, D. Parry, H. Tahara, S. Stone, and G. Peters. 1996. Regulation of p16CDKN 2 expression and its implications for cell immortalization and senescence. Mol. Cell. Biol. 16: 859-867.

Hayflick, L. and P.S. M oorhead. 1961. The serial cultivation of human diploid cell strains. Exp. Cell Res. 25: 585-621.

Hunter, T. 1991. Cooperation between oncogenes. Cell 64: 249270.

Kamijo, T., F. Zindy, M.F. Roussel, D.E. Quelle, J.R. Downing, R.A. A shmun, G. Grosveld, and C.J. Sherr. 1997. Tumor suppression at the mouse IN K4a locus mediated by the al ternative reading frame product p19ARF. Cell 91: 649-659.

Kauffmann-Zeh, A., P. Rodriguez-Viciana, E. Ulrich, C. Gilbert, P. Coffer, J. Downward, and G. Evan. 1997. Suppression of C-Myc-induced apoptosis by Ras signalling through PI(3)K and PKB. Nature 385: 544-548.

Kinsella, T.M. and G.P. N olan. 1996. Episomal vectors rapidly and stably produce high-titer recombinant retrovirus. Hum. Gene Ther. 7: 1405-1413.

Kulju, K.S. and J.M. Lehman. 1995. Increased p53 protein associated with aging in human diploid fibroblasts. Exp. Cell Res. 217: 336-345.

Lees, E. 1995. Cyclin dependent kinase regulation. Curr. Biol. 7: 773-780.

Lin, A.W., M. Baradas, J.C. Stone, L. van A elst, M. Serrano, and S.W. Lowe. 1998. Premature senescence involving p53 and p16 is activated in response to constitutive MEK/M APK signaling. Genes \& Dev. (this issue).

Lloyd, A.C., F. Obermuller, S. Staddon, C.F. Barth, M. M cMahon, and H. Land. 1997. Cooperating oncogenes converge to 
regulate cyclin/cdk complexes. Genes \& Dev. 11: 663-677.

Loughran, O., L.J. Clark, J. Bond, A. Baker, I.J. Berry, K.G. Edington, I.S. Ly, R. Simmons, R. Haw, D.M. Black, R.F. N ewbold, and E.K. Parkinson. 1997. Evidence for the inactivation of multiple replicative lifespan genes in immortal human squamous cell carcinoma keratinocytes. Oncogene 14: 1955-1964.

Marais, R., Y. Light, H. Paterson, and C.J. Marshall. 1995. Ras recruits Raf- 1 to the plasma membrane for activation by tyrosine phosphorylation. EMBO J. 14: 101-110.

Marshall, C.J. 1994. MAP kinase kinase kinase, MAP kinase kinase and MAP kinase. Curr. O pin. Genet. Dev. 4: 82-89.

Marshall, C.J. 1995. Specificity of receptor tyrosine kinase signaling: Transient versus sustained extracellular signal-regulated kinase activation. Cell 80: 179-185.

-_-. 1996. Ras effectors. Curr. Opin. Cell Biol. 8: 197-204.

McConnell, B.B., M. Starborg, S. Brookes, and G. Peters. 1998. Inhibitors of cyclin-dependent kinases induce features of replicative senescence in early passage human di ploid fibroblasts. Curr. Biol. 8: 351-354.

Merlo, A., J.G. Herman, L. Mao, D.J. Lee, E. Gabrielson, P.C. Burger, S.B. Baylin, and D. Sidransky. 1995. 5' CpG island methylation is associated with transcriptional silencing of the tumour suppressor p16/CDKN2/MTS1 in human cancers. Nat. Med. 1: 686-692.

Meyerson, M., C.M. Counter, E.N. Eaton, L.W. Ellisen, P. Steiner, S.D. Caddle, L. Ziaugra, R.L. Beijersbergen, M.J. Davidoff, Q. Liu, S. Bacchetti, D.A. Haber, and R.A. Weinberg. 1997. hEST 2, the putative human tel omerase catalytic subunit gene, is up-regulated in tumor cells and during immortalization. Cell 90: 785-795.

Miller, A.D. and G.J. Rosman. 1989. Improved retroviral vectors for gene transfer and expression. BioTechniques 7: 980-990.

Morgenstern, J.P. and H. Land. 1990. Advanced mammalian gene transfer: High titre retroviral vectors with multiple drug selection markers and a complementary hel per-free packaging cell line. Nucleic Acids Res. 18: 3587-3596.

N oda, A., Y. Ning, S.F. Venable, O.M. Pereira-Smith, and J.R. Smith. 1994. Cloning of senescent cell-derived inhibitors of DNA synthesis using an expression screen. Exp. Cell Res. 211: 90-98.

O'Shea, C.C., T. Crompton, I.R. Rosewell, A.C. Hayday, and M.J. Owen. 1996. Raf regulates positive selection. Eur. J. Immunol. 26: 2350-2355.

Pear, W.S., G.P. N olan, M.L. Scott, and D. Baltimore. 1993. Production of high-titer hel per-free retroviruses by transient transfection. Proc. Natl. Acad. Sci. 90: 8392-8396.

Pomerantz, J., N . Schrei ber-Agus, N J. Liégeois, A. Silverman, L. Alland, L. Chin, J. Potes, K. Chen, I. Orlow, H.W. Lee, C. Cordon-Cardo, and R.A. DePinho. 1998. The Ink4a tumor suppressor gene product, p19Arf, interacts with MDM 2 and neutralizes MDM2's inhibition of p53. Cell 92: 713-723.

Quelle, D.E., F. Zindy, R.A. Ashmun, and C.J. Sherr. 1995. Alternative reading frames of the IN K4a tumor suppressor gene encode two unrel ated proteins capable of inducing cell cycle arrest. Cell 83: 993-1000.

Reznikoff, C.A., T.R. Yeager, C.D. Belair, E. Savelieva, J.A. Puthenveettil, and W.M. Stadler. 1996. Elevated p16 at senescence and loss of p16 at immortalization in human papillomavirus $16 \mathrm{E} 6$, but not E7, transformed human uroepithelial cells. Cancer Res. 56: 2886-2890.

Samuels, M.L., M.J. Weber, J.M. Bishop, and M. McMahon. 1993. Conditional transformation of cells and rapid activation of the mitogen-activated protein kinase cascade by an estradiol-dependent human raf-1 protein kinase. Mol. Cell. Biol. 13: 6241-6252.
Scheffner, M., B.A. Werness, J.M. Huibregtse, A.J. Levine, and P.M. Howley. 1990. The E6 oncoprotein encoded by human papillomavirus types 16 and 18 promotes the degradation of p53. Cell 63: 1129-1136.

Serrano, M., H. Lee, L. Chin, C. Cordon-Cardo, D. Beach, and R.A. DePinho. 1996. Role of the IN K4a locus in tumor suppression and cell mortality. Cell 85: 27-37.

Serrano, M., A.W. Lin, M.E. McCurrach, D. Beach, and S.W. Lowe. 1997. Oncogenic ras provokes premature cell senescence associated with accumulation of p53 and p16INK4a. Cell 88: 593-602.

Shay, J.W. and S. Bacchetti. 1997. A survey of telomerase activity in human cancer. Eur. J. Cancer 33: 787-791.

Stanton, V.J., D.W. Nichols, A.P. Laudano, and G.M. Cooper. 1989. Definition of the human raf amino-terminal regulatory region by deletion mutagenesis. Mol. Cell. Biol. 9: 639-647.

Sugrue, M.M., D.Y. Shin, S.W. Lee, and S.A. Aaronson. 1997. Wild-type p53 triggers a rapid senescence program in human tumor cells lacking functional p53. Proc. Natl. Acad. Sci. 94: 9648-9653.

Takagi, S., M.L. McFadden, R.E. Humphreys, B.A. Woda, and T. Sairenji. 1993. Detection of 5-bromo-2-deoxyuridine (BrdU rd) incorporation with monoclonal anti-BrdU rd antibody after deoxyribonuclease treatment. Cytometry 14: 640-648.

Thorburn, J., M. M CM ahon, and A. Thorburn. 1994. Raf-1 kinase activity is necessary and sufficient for gene expression changes but not sufficient for cellular morphology changes associated with cardiac myocyte hypertrophy. J. Biol. Chem. 269: 30580-30586.

Treisman, R. 1996. Regulation of transcription by MAP kinase cascades. Curr. Opin. Cell Biol. 8: 205-215.

van Steensel, B., A. Smogorzewska, and T. de Lange. 1998. TRF2 protects human telomeres from end-to-end fusions. Cell 92: 401-413.

Woods, D., D. Parry, H. Cherwinski, E. Bosch, E. Lees, and M. M CM ahon. 1997. Raf-induced proliferation or cell cycle arrest is determined by the level of Raf activity with arrest mediated by p21Cip1. Mol. Cell. Biol. 17: 5598-5611.

Zhang, Y., Y. Xiong, and W.G. Yarbrough. 1998. ARF promotes MDM 2 degradation and stabilizes p53: ARF-IN K4a locus deletion impairs both the $\mathrm{Rb}$ and p53 tumor suppression pathways. Cell 92: 725-734.

Zindy, F., D.E. Quelle, M.F. Roussel, and C.J. Sherr. 1997. Expression of the p16INK4a tumor suppressor versus other IN K4 family members during mouse devel opment and aging. Oncogene 15: 203-211. 


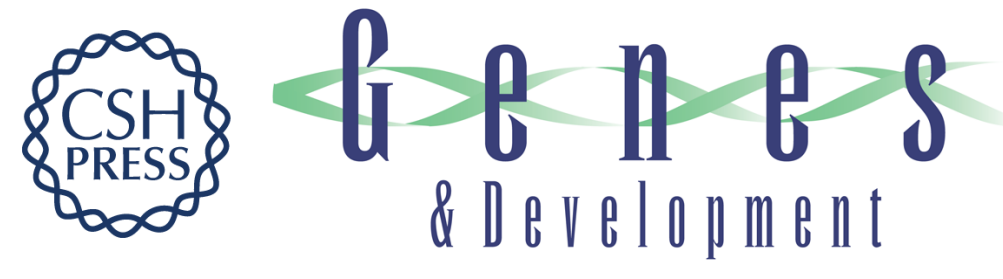

\section{Senescence of human fibroblasts induced by oncogenic Raf}

Jiyue Zhu, Douglas Woods, Martin McMahon, et al.

Genes Dev. 1998, 12:

Access the most recent version at doi:10.1101/gad.12.19.2997

References This article cites 48 articles, 14 of which can be accessed free at: http://genesdev.cshlp.org/content/12/19/2997.full.html\#ref-list-1

License

Email Alerting Receive free email alerts when new articles cite this article - sign up in the box at the top Service right corner of the article or click here.

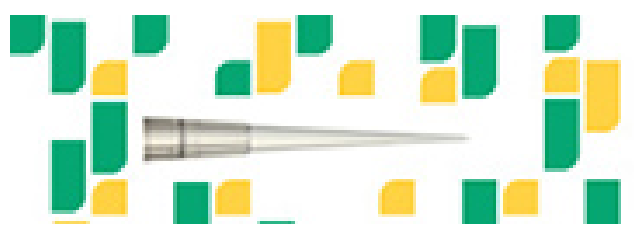

Focused on your science. 